\title{
NUTRITIONAL ASSESSMENT OF CHILDREN AND TEENAGERS WITH DOWN SYNDROME AND CONGENITAL CARDIOPATHY
}

\section{EVALUACIÓN NUTRICIONAL DE NIÑOS Y ADOLESCENTES CON SÍNDROME DE DOWN Y CARDIOPATÍA CONGÉNITA}

\author{
Bruna Senna Rodrigues (1), Lúcia Campos Pellanda (1), Catarina Bertaso Andreatta Gottschall (2) \\ (1) Instituto de Cardiologia do Rio Grande do Sul. \\ Universidade Federal de Ciências da Saúde de Porto Alegre, RS, Brasil, \\ (2) Universidade Federal de Ciências da Saúde de Porto Alegre, RS, Brasil.
}

\begin{abstract}
The aim of this study was to analyze the nutritional status of patients with Down Syndrome (DS) and congenital heart defect (CHD). A transversal study which assessed the nutritional profile of DS and CHD patients between 0 and 18 years of age was done. Weight and stature, both at birth and current were considered. A total of 98 patients, 56\% female were analyzed. Prevalence of low weight, overweight and low stature at the current anthropometric data (CAD) was 30\%, $22 \%$ and $17 \%$, respectively. There was a statistically significant difference between malnutrition at birth and the $C A D(p<0.01)$. The current weight/age $(W / A)$ ratio showed significant increase as compared to birth W/A ( $p=<0.05)$. In addition, there was also stature recovery based on stature/age $(S / A)$ ratio $(p<0,001)$. In conclusion, at birth, these patients present stature and weight deficit but as age advances there is a stature improvement; however it is not properly accompanied by the weight, since there is a tendency towards overweight in puberty.
\end{abstract}

Key words: Down syndrome; congenital heart defect; nutrition assessment; obesity; malnutrition.

Este trabajo fue recibido el 27 de Junio de 2011 y aceptado para ser publicado el 15 de Abril de 2012.

\section{INTRODUCTION}

Down Syndrome (DS) results from trisomy of human chromosome 21, which determines, among other characteristics, mental and growth retardation (1-3). DS has an annual incidence of 1/800 living births worldwide and 8 thousand births in Brazil (3-5). Maternal age above 35 is one of the main risk factors for the development of such genetic defects (6). The main causes of death in DS patients are congenital cardiac complications. Nevertheless, thanks to medical advances both in therapeutics and diagnostics, life expectancy of such patients has increased dramatically over the last decades (4,7-9).

Approximately $40 \%$ of children with DS have congenital cardiopathies, the most frequent congenital malformation linked to DS (9). Half of those children present Atrioventricular Septal Defect (AVSD), which is much rarer in normal individuals. Other congenital cardiopathies such as Interatrial Communication (IAC), Interventricular Communication (IVC) and Patent Ar- terial Duct (PAD) are also more frequent in DS patients (8-11).

Evaluation of nutritional status is usually performed through anthropometry. Special characteristics of DS patients, which are inherent to their condition, are considered in the curves suggested by Cronk and collaborators $(7,12)$. These curves were elaborated based on the American population data and consider morbidities as hypothyroidism and congenital cardiac diseases $(2,13,14)$.

It is known that weight and stature are significantly lower in children with cardiopathy, and low stature is one of the main characteristics of people with DS (4, $5,10-12)$.

Nutritional assessment studies of DS patients are scarce in the literature (2). Therefore, it is extremely important to develop such studies, which will provide health care professionals with suitable tools and information that can adapt to the features of their target 
population $(2,16)$.

The objective of this study was to analyze the nutritional profile of children with DS and congenital cardiopathy from a public pediatric ambulatory specialized in cardiology, of the unified public Health Care System, in Porto Alegre - RS, Brazil.

\section{SUBJECTS AND METHODS}

This is a cross-sectional study in which ambulatory patients with DS and congenital cardiopathy, between 0 and 18 years (both male and female) were assessed. They were all admitted at the public pediatric ambulatory of Instituto de Cardiologia, Porto Alegre - RS, between January and July of 2010.

The project was approved by the Ethic Committee of the Instituto de Cardiologia do Rio Grande do Sul under authorization number 4389/09. After a detailed explanation on the study, it was handed and addressed to the patient's legal guardian an informed free consent term. The study included only patients whose legal guardian consented their participation by agreeing and signing the term.

The responsible relatives answered a questionnaire with questions on their educational level, pregnancy period, previous cardiac surgical procedure, type of cardiopathy, anthropometrical data of the child (or teenager) at birth as well as of today.

The nutritional evaluation of the patients was performed by the researchers in an objective way as follows. The measurement of the weight of children up to 2 years of age was done using a Balmak mechanical weighing scale with capacity of maximum $16 \mathrm{~kg}$ and $5 \mathrm{~g}$ accuracy. Children above 2 years of age were weighed on a Welmy electronic weighing scale with capacity of maximum $150 \mathrm{~kg}$ and accuracy of $50 \mathrm{~g}$. Children were barefoot and with light clothing during weighing, according to international standards (17).

The stature of the children up to 2 of age was obtained with the use of an infantometer with accuracy of 0.1 $\mathrm{cm}$, having the child lying stretched over a plain surface. For children older than 2 years of age, a stadiometer with accuracy of $0.1 \mathrm{~cm}$ was used, having the patient in vertical position, legs together and barefoot.

Children ages were calculated by taking the date on which they had their stature and weight measured and subtracting it by the date obtained on their vaccination cards, birth certificate and / or informed by their responsible relative.

In order to classify the nutritional status of the studied individuals, the weight/age (W/A) and stature/age (S/A) ratios were used and expressed in comparison to the median of the reference population (12). The cut-off point for low W/A was percentile values below 10th (for children up to 3 years of age) and below 5th (for those older than 3 years of age). For overweight, percentile values above 95 th were used. The cut-off points for low S/A were percentiles lower than 10th (for those up to 3 years of age) and lower than 5th (for those older than 3 years of age).

The data was stored and analyzed using the statistical package software SPSS version 18.0. The qualitative variables were obtained from absolute and relative frequencies. In order to compare the patient's nutritional status, both at birth and current, for weight and stature, Wilcoxon non-parametric $t$ tests were used. To evaluate the relation between malnutrition and the qualitative variables, the Chi-Square test was utilized. The relation between the presence or absence of birth and current malnutrition, considering weight and stature, was done by using McNemar non-parametric test. The significance level adopted was of $5 \%$.

\section{RESULTS}

Ninety-eight patients from the public pediatric ambulatory of Instituto de Cardiologia de Porto Alegre - RS were evaluated. The studied population was composed by $56.1 \%$ girls $(n=55)$ and $43.9 \%$ boys $(n=43)$, with ages between 0 and 18 . The most frequent age group was the one with individuals between 10 and 18 years of age, $(40.8 \%)(n=40)$, while the least frequent was of children between 6 and 10 years of age, representing $11.2 \%$ $(n=11)$ of the studied population. The gestational time was predominantly of term births ( $\geq 38$ weeks), (77.6\%).

Most of the mothers, $66.3 \%$ ( $n=65)$, were older than 35 at the child's birth. In terms of maternal education, $61.2 \%(n=60)$ had attended primary school, however only $28.3 \%(\mathrm{n}=17)$ of these completed this initial educational level. The rest, $71.7 \%(n=43)$, have not completed their studies. Mothers with higher education represented $7.2 \%(n=7)$, being $42.9 \%$ of these $(n=3)$ incomplete and $57.1 \%(n=4)$ completed degrees.

Of the evaluated patients, $50 \%(n=49)$ had already undergone some cardiac surgical procedure, most of them $(39 \%, n=38)$ before turning 2 years of age. There was no association between the type of cardiopathy and the nutritional status $(\mathrm{p}>0,05)$. Of the different congenital cardiopathies found in the studied population $50 \%$ $(n=49)$ of the individuals presented AVSD, 28\% $(n=27)$ IVC, $24 \%(n=23)$ with problems in the IAC, $22 \%(n=21)$ with a flaw PAD and $13 \%(n=13)$ with Tetralogy of Fallot (TOF) (table 1).

As for the nutritional status at birth, it could be observed from the W/A curve that $31 \%(n=30)$ of the individuals presented low weight for their ages. Accor- 
ding to the S/A curve, $42 \%(n=41)$ of the children were born with stature below normality.

Of the 98 patients, $52 \%(n=51)$ had difficulty to increase put on weight in the first months following birth, while only $26 \%(n=26)$ of them had adequate weight gain at this phase; the responsible relatives of the remaining patients $22 \%(\mathrm{n}=21)$ were not able to report regarding weight gain of their children in the first months following birth.

However, in the current nutritional status evaluation, a tendency towards gain weight by these individuals could be noticed. Overweight, based on the W/A, has been diagnosed in $22 \%(n=22)$ of the studied population. The number of evaluated patients with low weight was the same found at birth age, $31 \%(n=30)$. Regarding the S/A curve, $17 \%(n=17)$ of the cases presented low stature

\section{TABLE 1}

General characteristics of the 98 children and teenagers with DS and congenital cardiopathy

\begin{tabular}{|c|c|c|}
\hline & Variables & n $(\%)$ \\
\hline \multirow[t]{3}{*}{ Patients } & $98(100)$ & \\
\hline & Females & $55(56,1)$ \\
\hline & Males & $43(43,9)$ \\
\hline \multicolumn{3}{|l|}{ Age } \\
\hline & 0 to 2 years & $24(25)$ \\
\hline & 2 to 6 years & $23(23)$ \\
\hline & 6 to 10 years & $11(11)$ \\
\hline & 10 to 18 years & $40(41)$ \\
\hline \multicolumn{3}{|c|}{ Gestational Age } \\
\hline & Term & $76(77,6)$ \\
\hline & Pre-term & $22(22,4)$ \\
\hline \multicolumn{3}{|c|}{ Maternal Age } \\
\hline & Up to 20 years & $4(4)$ \\
\hline & 21 to 34 years & $29(30)$ \\
\hline & More than 35 years & $65(66)$ \\
\hline \multicolumn{3}{|c|}{ Maternal Schooling } \\
\hline & No answer & $2(2)$ \\
\hline & Illiterate & $0(0)$ \\
\hline & Primary School (Incomplete) & $43(43,9)$ \\
\hline & Primary School (Complete) & $17(17,3)$ \\
\hline & High School (Incomplete) & $5(5,1)$ \\
\hline & High School (Complete) & $24(24,5)$ \\
\hline & Higher Education (Incomplete) & $3(3,1)$ \\
\hline & Higher Education (Complete) & $4(4,1)$ \\
\hline Cardiac & Surgical Procedure & $49(50)$ \\
\hline & Up to 2 years & $38(39)$ \\
\hline & 2 to 6 years & $8(8)$ \\
\hline & More than 6 years & $3(3)$ \\
\hline \multicolumn{3}{|c|}{ Type of Cardiopathy } \\
\hline & AVSD & $49(50)$ \\
\hline & IVC & $27(28)$ \\
\hline & IAC & $23(24)$ \\
\hline & PAD & $21(22)$ \\
\hline & TOF & $13(13)$ \\
\hline
\end{tabular}


for their ages (table 2, figure 1 and 2).

There was a statistically significant difference between malnutrition frequency at birth and current nutrition status of the studied population based on

TABLE 2

Birth and current anthropometric data of the 98 children and teenagers with DS and congenital cardiopathy.

\begin{tabular}{|c|c|c|}
\hline & Variables & n $(\%)$ \\
\hline Patients & & $98(100)$ \\
\hline \multicolumn{3}{|c|}{ Weight at Birth } \\
\hline & Low weight & $30(31)$ \\
\hline & Eutrophy & $62(63,3)$ \\
\hline & Overweight & $6(6,1)$ \\
\hline \multicolumn{3}{|c|}{ Stature at Birth } \\
\hline & Low Stature & $41(42)$ \\
\hline & Regular Stature & $57(58,2)$ \\
\hline & Difficulty to Gain Weight & $51(52)$ \\
\hline & Adequate Gain of Weight & $26(26)$ \\
\hline \multicolumn{3}{|c|}{ Current Weight } \\
\hline & Low weight & $30(31)$ \\
\hline & Eutrophy & $46(46,9)$ \\
\hline & Overweight & $22(22)$ \\
\hline \multicolumn{3}{|c|}{ Current Stature } \\
\hline & Low Stature & $17(17)$ \\
\hline & Regular Staturel & $81(82,7)$ \\
\hline
\end{tabular}

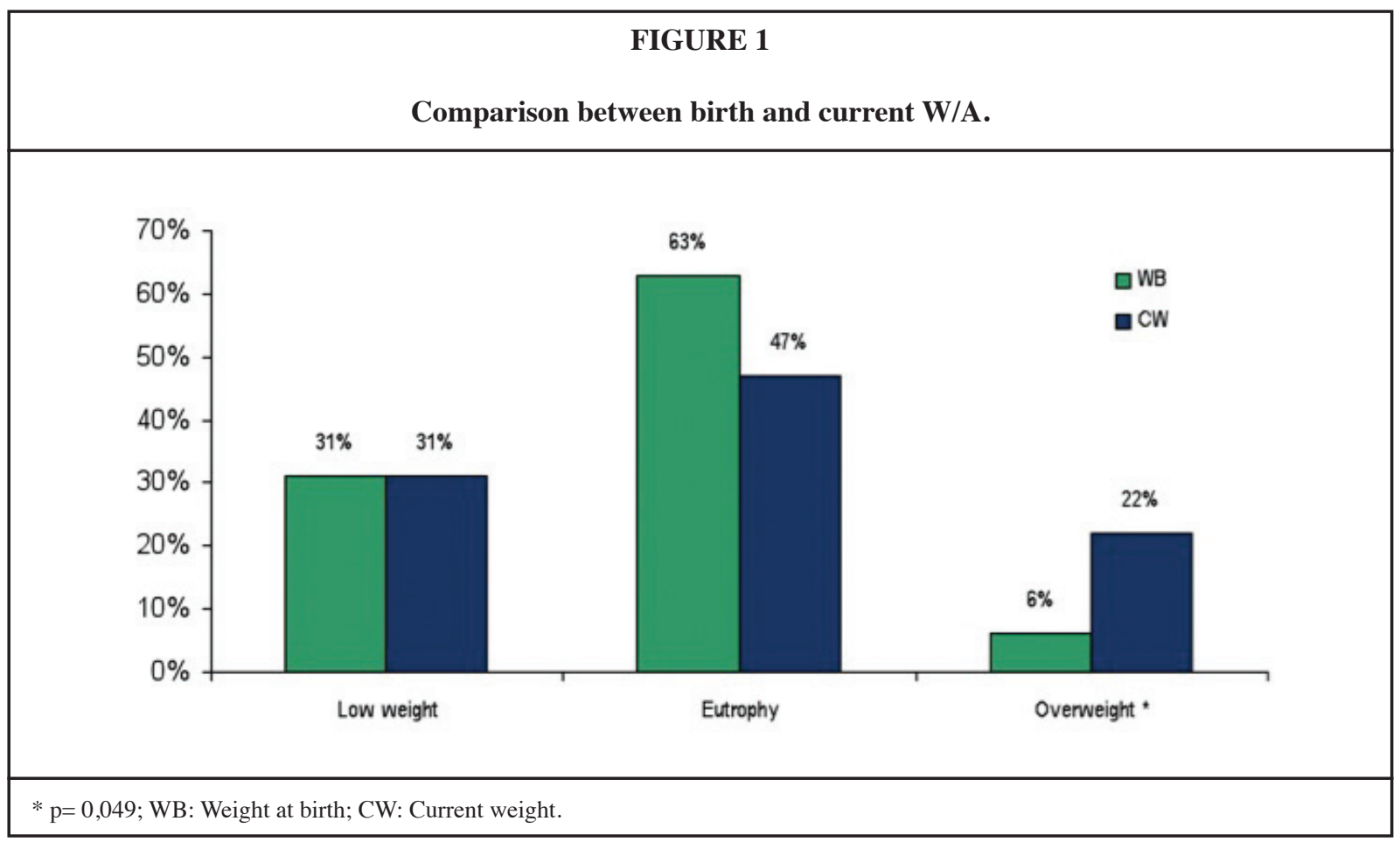


anthropometric data $(52 \%$ Vs $34 \%)(\mathrm{p}<0.01)$ (table 3$)$. The relationship between age and malnutrition showed a border line linear association $(\mathrm{p}=0.057)$ of nutritional status improvement as age increased.

The connection between current and birth W/A ratio showed significant worsening in the nutritional status linked to overweight $(\mathrm{p}<0.05)$. Furthermore, there was statistical significant association $(\mathrm{p}<0.001)$ between birth and current $\mathrm{S} / \mathrm{A}$, pointing towards a stature growth recovery (figures 1,2 ).

The most prevalent maternal education status, when added to birth and current nutritional status, was the primary school level (completed or not), although not significantly associated to malnutrition.

The study did not show significant results when relating cardiopathy and malnutrition, nor was any nutritional status improvement noticeable after cardiac surgical procedure.

\section{DISCUSSION}

This cross-sectional study on children and teenagers with DS and congenital cardiopathy showed that such patients present stature and weight deficit at birth. As age increases, there is stature growth improvement, however this is not properly followed by weight. At contrary, it was observed that these patients show a greater propensity towards overweight along the years.

The Moura and collaborators study 18 which evaluated 18 individuals, being 6 males $(33.3 \%)$ and 12 females $(66.6 \%)$, showed similar results to ours, presenting

\section{FIGURA 2}

\section{Comparison between birth and current S/A.}

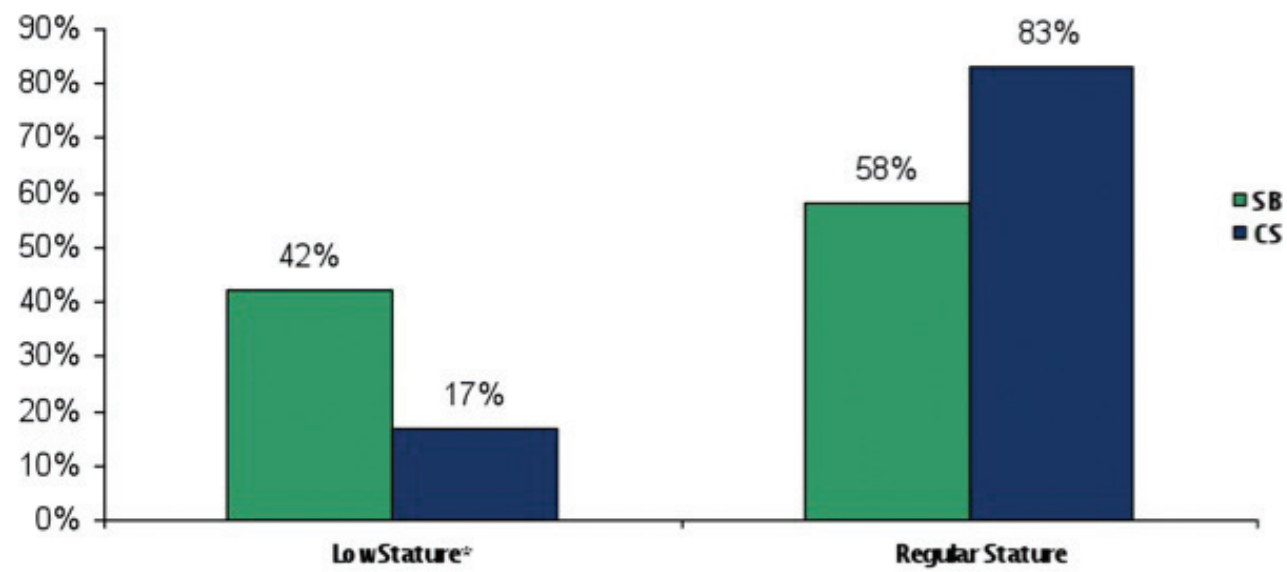

* $\mathrm{p}=0,049 ; \mathrm{SB}:$ Stature at birth; CS: current stature.

TABLE 3

Relation between birth and current malnutrition of the 98 children and teenagers with DS and congenital cardiopathy.

Variables n $(\%)$

Birth malnutrition

Current malnutrition

$33(34)$

$* \mathrm{p}=0,01$ 
greater prevalence of DS and congenital cardiopathy in females.

As for prematurity, it was not found any association between premature birth and DS or congenital cardiopathy. In our study, as well as in Theodoro's (19), there was greater prevalence of term births.

According to Freeman and collaborators (20), more studies on the relation of maternal age and DS are necessary, although advanced maternal age is a risk factor for DS. At the biological point of view, what is more important is the physiological age of the ovary. One possible explanation would be that at advanced age there is ovule depletion. Then, women with reduced number of ovules, for other reasons, may have greater risk of conception with a trisomy of chromosome 21 . The Binkert and collaborators (21) study, for instance, indicated positive correlation between the mothers' advanced age and the risk of conceiving a DS child, although the pathological mechanism remained unclear.

In line with the study of Lopes and collaborators (15), as well as Zini (22), regarding maternal education, most mothers had not completed primary school.

The individuals of the study showed impairment in weight and stature development, being both significantly lower than normal, in agreement with the results of other studies (10-12, 15, 23). Theodoro (19) highlights that babies with DS are born with discrete retardation in their growth and with lower percentiles regarding the ratio weight/stature. This particular growth profile is characterized by a premature trigger of the growth spurt and reduced linear growth velocity, which result in individuals with lower stature than the general population $(7,8,12)$. Besides that, there is propensity for overweight, usually starting from puberty. This fact is related to growth deficit itself, which determines a lower basal metabolic rate $(7,14,24-26)$. According to Moura and collaborators (18) and Benato and collborators (27), DS individuals present greater probability of thyroid dysfunction (hypothyroidism), which can be the cause for overweight and obesity. These studies suggest that the slower basal metabolic rate, the compulsive feeding due to difficulty in chewing and the general hypotony of the muscles (including those involved in digestion) as possible causes of obesity in these individuals. Specially due to the hypotony of the muscles involved in digestion, DS patients experience less satiation feeling after a meal, and this make them eat more.

Theodoro (19) considers the low stature a contributing factor to obesity, since this aspect diminishes the daily energetic need and consequently contributes for the caloric ingestion above necessary. He also links obesity with chronic diseases in adulthood, especially cardiac ones. Therefore, children with DS who develop obesity in their first year and remain obese until adulthood have greater risks of developing cardiovascular diseases. Silva e collaborators (28) report a greater concentration of visceral fat and higher percentage of overweight in people with DS If compared to regular population.

Benato and collaborators (27) show that children with DS in association with severe congenital cardiac disease present feeding problems and weight gain below expected. Many aspects of the treatment of such cardiac diseases may affect the ability of these children to increase weight normally, among them: admissions, treatment and/or surgery, all leading to difficulties in weight gain and resulting in a low weight child (29). Respiratory and suction problems are also clinical manifestations that commonly lead to nutritional difficulty in this group. In cardiopathic infants, the act of sucking is an activity that requires a lot of effort. It can cause excessive fatigue and aggravate the dyspnea scenario. In older children, the respiratory difficulty and fatigue interfere with the capacity of chewing and swallowing (30). However, as soon as the congenital cardiac defect is repaired, children with DS start to increase weight adequately. We believe that the absence of statistical significance in the association between cardiac defect repair and nutritional status improvement observed in this study may be explained by the small size of the analyzed sample and/or the lack of a control group composed of patients who do not have congenital cardiopathy in our study.

Others have found a connection between the frequency of malnutrition at birth and later on in life. These studies present evidence suggesting that as age increase, the nutritional status improve. Nevertheless, if on one hand there has been stature growth recovery based on $\mathrm{S} / \mathrm{A}$ ratio data, on the other hand there has been tendency towards overweight from W/A ratio data $(7,14,24-26)$.

In a study by Cronk (12) made in England with 262 DS patients between 2 and 18 years of age, the authors showed that at least $30 \%$ of the individuals presented some degree of overweight (22).

Gomes and collaborators (31), in a study designed to investigate the incidence of overweight and obesity in children with DS, it has been found that $83 \%$ of children with ages between 2 and 6 are within the normal weight standards, while $17 \%$ are overweight or obese $(31,32)$. In other two studies, by Giaretta and collaborators (4) and Fernahall (33), it was noticed that $33.3 \%$ of adolescents with DS are overweight, $33.3 \%$ are well-nourished and $33.3 \%$ malnourished. These findings reinforce the results found in other studies on children and teenagers with DS - which showed an increase in the prevalence of obesity ever since the childhood $(32,33)$. This data 
demonstrates the importance of the nutritional followup in order to prevent overweight and obesity of this population $(32,33)$.

As in the work by Ferrin and collaborators (34), our study showed prevalence in the type of congenital cardiopathy found - half of the evaluated individuals presented AVSD (8-11). However, there was no association between the type of cardiopathy and malnutrition, nor there was any nutritional status improvement after cardiac surgical procedure.

The information found in studies such as this one is of great value for establishing a general profile of patients with DS and congenital cardiopathy. Such information is also important as basis to new researches, since this is an understudied population. Furthermore, DS populations have gone through significant profile changes over the past years, especially due to the increase in their life expectancy.

The existing curves used in this study do not show a specific cut-off point for the population with DS; thus, it was chosen to use the standard cut-off points recommended by the international organizations for children and teenagers without DS. It was noticed that DS children, just like the regular population, also need to be anthropometrically evaluated based on curves of $\mathrm{W} / \mathrm{S}$ and Body Mass Index for age (BMI/A), since the existing curves underestimate excess of weight and overestimate low weight of these individuals.

\section{CONCLUSION}

The individuals evaluated in this study presented stature and weight deficit at birth and, as age increased, they improved their stature profile. We can no longer link DS and congenital cardiopathy to malnutrition. Nowadays, these patients have been going through a nutritional transition: they are becoming individuals with overweight and obesity and leaving the malnourished group they used to be part of.

It is during puberty that these patients are developing overweight, and that is reflecting a greater risk for the development of chronic diseases in adulthood. Our study showed evidence of high overweight prevalence among those people. Therefore, public health care policies should take into consideration the particularities of the DS population. In addition, new international growth curves must be constructed and consider the comorbidities associated with this population.

\section{RESUMEN}

El objetivo del esto estudio fue analizar el perfil nutricional de las pacientes con síndrome de Down (SD) y cardiopatía congênita (CC). Se trata de un estudio transversal de avaluación del estado nutricional en 98 pacientes con SD y CC, $56 \%$ mujeres entre 0 y 18 años de edad. La prevalencia de bajo peso, sobrepeso y baja estatura fue de $30 \%, 22 \%$ y $17 \%$, respectivamente. Hubo diferencia entre la desnutrición al nacer y la que se refiere a los actuales datos antropométricos $(\mathrm{p}=0,01)$. Una asociación mostró un incremento significativo en el peso ( $\mathrm{p}=0,049)$ y hubo recuperación del estatura $(\mathrm{p}<0,001)$. En conclusión, el nacimiento hay déficit de estatura y peso. Al aumentar la edad hay una mejoría en la estatura, pero no así en el peso. Se observó una predisposición al sobrepeso en estos pacientes.

Palabras clave: síndrome de Down, cardiopatía congénita, evaluación nutricional, obesidad, malnutrición.

Author correspondence:

Catarina B A Gottschall

R. Sarmento Leite, 245

CEP 90050-170

Porto Alegre, RS, Brasil

Teléfonos: 55513303.8743

Fax. 555133038830

E-mail: catarina@ufcspa.edu.br

\section{REFERENCES}

1. Guitti JC. Epidemiological characteristics of congenital heart diseases in Londrina, Parana south Brazil. Arq Bras Cardiol 2000;74(5):395-404.

2. Grech V, Gatt M. Syndromes and malformations associated with congenital heart disease in a population-based study. Int J Cardiol 1999;68(2):151-6.

3. Prado MB, Mestrinheri L, Frangella VS, Mustacchi Z. Acompanhamento nutricional de pacientes com Síndrome de Down atendidos em um consultório pediátrico. O mundo da saúde 2009;33(3):335-46.

4. Granzotti JA, Paneto IC, Amaral FV, Nunes MA. Incidência de cardiopatias congênitas na Sindrome de Down / Incidence od heart defects in Down syndrome. J Pediatr 1995;71(1):28-30.

5. Reller MD, Morris CD. Is Down syndrome a risk factor for poor autcome after repair of congenital heart defects? J Pediatr 1998;132(4):738-41.

6. Castilla EE, Orioli IM. ECLAMC: the LatinAmerican collaborative study of congenital malformations. Community Genet 2004;7(2-3):76-94.

7. Chen CW, Li CY, Wang JK. Growth and development of children with congenital heart disease. J Adv Nurs 2004;47(3):260-9.

8. Pinheiro AC, Urteaga C, Canete G, Atalah E. Evaluación del estado nutricional em ninos com síndrome de down según diferentes referencias antropométricas. Rev Chil Pediatr 2003;74(6):585-89. 
9. Luft VC, Mello ED. Síndrome De Down: Supervisão Em Saúde, Aspectos E Manejo Nutricional. Nutrição Pauta 2006;16(78):19-23.

10. Tambic-Bukovac L, Malcic I. Growth and development in children with congenital heart defects. Lijec Vjesn 1993;115(3-4):79-84.

11. Casells S, Wisniewski KE. Growth hormone treatment in down's syndrome. Pediatrics 1993; 124(1): 158 .

12. Cronk C, Crocker AC, Pueschel SM, Shea AM, Zackai E, Pickens G, et al. Growth tables for children with Down syndrome: 1 month to 18 years of age. Pediatrics 1988;81(1):102-10.

13. Miyague NI, Cardoso SM, Meyer F, Ultramari FT, Araujo FH, Rozkowisk I, et al. Epidemiological study of congenital heart defects in children and adolescents: Analysis of 4,538 cases. Arq Bras Cardiol 2003;80(3):269-78.

14. Santos J, Franceschini S, Priore S. Curvas de crescimento para crianças com síndrome de down. Rev Bras Nutr Clin 2006;21(2):144-8.

15. Lopes TS, Ferreira DM, Pereira RA, Veiga G, Marins VR. Assessment of anthropometric indexes of children and adolescents with down syndrome. J Pediatr 2008;84(4):350-56.

16. Sobrinho JG. Programa de atenção à criança e ao adolescente portador da síndrome de Down. In: Segre CM, Junior MS, editores. Pediatria - Diretrizes Básicas Organização de Serviços. São Paulo: Sarvier; 2001. p. 185-98.

17. Silugem DM, Devinvenzi UM, Lessa AC. Diagnóstico do estado nutricional da criança e do adolescente. J Pediatr 2000;76(3):274-84.

18. Moura AB, Mendes A, Peri A, Passoni CRMS. Aspectos Nutricionais em Portadores da Síndrome de Down. Cadernos Da Escola de Saúde 2009;2:1-11.

19. Theodoro LR. Sobrepeso e obesidade na síndrome de Down: estudo de fatores relacionados ao ganho de peso em adolescentes [dissertação]. São Paulo (SP): Universidade Presbiteriana Mackenzie; 2007.

20. Freeman SB, Yang Q, Allran K, Taft LF, Sherman SL. Women with a Reduced Ovarian Complement May Have an Increased Risk for a Child with Down Syndrome. Am J Hum Genet 2000;66(5):1680-3.

21. Binkert F, Mutter M, Schinzel A. Impact of prenatal diagnosis on the prevalence of live births with Down syndrome in the eastern half of Switzerland 19801996. Swiss Med Wkly 2002;132(33-34):478-84.

22. Zini B, Ricalde SR. Características nutricionais das crianças e adolescentes portadoras de síndrome de Down da APAE de Caxias do Sul e São Marcos -
RS. Pediatria 2009;31(4):252-9.

23. Viuniski N. Avaliação Nutricional em Crianças

24. Especiais Nutriçãa Pauta 2003:11(59) 20-3 ergy expenditure in children with Down syndrome: correcting metabolic rate for movement. J Pediatr $1994 \cdot 125 \cdot 829-38$

25. Luke A, Sutton M, Schoeller DA, Roizen NJ. Nutrient intake and obesity in prepubescent children with Down syndrome. J Am Diet Assoc 1996:96(12):1262-7

26. Rubin SS Rimmer JH, Chicoine B, Braddock D, McGuire DE. Overweight prevalence in persons with Down syndrome. Ment Retard 1998;36(3):17581.

27. Benato CV, Vicentino D, Silva EF, Matos JB, Gonçalves M, Santos J, et al. Levantamento Epidemiológico da Pressão Arterial e Avaliação Nutricional em Crianças com Síndrome de Down na Escola Especial Apae no Município de Umuarama - Pr. Arq Ciên Saúde da Unipar 2004;8(1).

28. Silva NM, Filho AG, Silva SF, Filho JF. Indicadores antropométricos de obesidade em portadores da síndrome de Down entre 15 e 44 anos. Rev bras Educ Fís Esporte 2009;23(4):415-24.

29. Damas BGB. A necessidade de informação e suporte aos pais de crianças portadoras de cardiopatia congênita [dissertação]. São Paulo (SP): Escola de Enfermagem da Universidade de São Paulo; 2008.

30. O'brien P. A criança com disfunção cardiovascular. IN: Hockenberry MJ. Wong, editor. Fundamentos de enfermagem pediátrica. Rio de Janeiro: Elsevier; 2006. p. 839-86.

31. Gomes AF, Amorim STS. Consumo alimentar e avaliação nutricional das crianças com Síndrome de Down em idade préescolar. In: $3^{\circ}$ Congresso Brasileiro sobre Síndrome de Down; 2000; Curitiba (PR), Brasil. Curitiba: Associação Reviver Down; 2000. p. 180-7.

32. Giaretta A, Ghiorzi AR. O ato de comer e as pessoas com Síndrome de Down. Rev Bras Enferm 2009;62(3):480-4.

33. Fernahall B, Figueroa A, Collier S, Goulopoulou S, Giannopoulou I, Baynard T. Resting Metabolic Rate is not Reduced in Obese Individuals with Down Syndrome. Ment Retard 2005;43(6):391-400.

34. Ferrín LM, Atik E, Ikari NM, Martins TC, Marcial MB, Ebaid M. Defeito Total do Septo Atrioventricular. Correlação Anatomofuncional entre Pacientes com e sem Síndrome de Down. Arq Bras Cardiol 1997;69(1):19-23. 